\title{
SUPERVISI PEMBELAJARAN KEPALA MADRASAH \\ DALAM MENINGKATKAN MUTU PEMBELAJARAN
}

\author{
Fedila Jelvita \\ fedilajelvita@gmail.com
}

\begin{abstract}
Abstrak
Upaya untuk meningkatkan mutu pembelajaran mengacu pada tugas pokok dan kompetensi kepala madrasah yaitu melaksanan supervisi pembelajaran. Dalam meningkatkaan mutu pembelajaran kepala sekolah/ madrasah dapat dilakukan dengan cara merencanakan supervisi pembelajaran dalam bentuk rancangan yang

tercantum dalam program kerja dan program supervisi kepala madrasah.
\end{abstract}

Kata Kunci: supervisi pembelajaran, kepala madrasah, mutu pembelajaran.

\section{A. Pendahuluan}

1. Pentingnya supervisi

Pada saat ini, pendidikan memegang peran penting dalam menentukan kualitas sumber daya maanusia (SDM), yang mana kualitas suatu bangsa dan negara tidak hanya ditandai dengan kekayaan alamnya, namun yang paling utama terletak pada keunggulan sumber daya manusia itu sendiri. Keunggulan sumber daya manusia tersebut berhubungan erat dengan mutu pendidikan. Mutu pendidikan tidak bisa terlepas dengan adanya proses pendidikan dan pengajaran yang berlangsung pada suatu lembaga pendidikan yang mengupayakan pengoordinasian secara sistematis dan terencana.

Hidayat dan Machali (Abadi, Yumnan., Akhyak \& Fuadi, 2019), menyebutkan bahwa upaya ke arah ini salah satunya dapat terwujud dengan adanya pelaksanaan supervisi. Supervisi mempunyai peran penting dalam upaya peningkatan kompetensi dan kemampuan profesional guru. Oleh karena itu, supervisi merupakan bagian yang sangat penting dan tidak bisa dipisahkan dalam upaya meningkatkan mutu pendidikan baik yang ada di sekolah maupun di madrasah.

Pentingnya supervisi juga tampak pada fenomena yang ada, bahwa pihak kementerian agama terus mengupayakan terwujudnya pelayanan pedidikan yang berkualitas terutama di madrasah, pelaksanaan supervisi 
diharapkan mampu: 1) meningkatkan kualitas dan profesionalisme guru dalam proses pembelajaran, 2) memberdayakan tim pelaksana supervisi pembelajaran di madrasah, 3) memfokuskan pada kompetensi profesional dan kompetensi pedagogik guru, 4) mengaktifkan fungsi dan tanggung jawab serta kewenangan kepala madrasah sebagai pelaku supervisi di lembaga madrasah. Dengan begitu jelas bahwa secara keseluruhan supervisi merupakan tugas pokok dan tanggung jawab kepala madrasah.

2. Rumusan Masalah

Bagaimana peran kepala madrasah dalam meningkatkan mutu pendidikan melalui kegiatan supervisi terutama dalam hal supervisi pembelajaran?

3. Tujuan

Untuk mendapatkan gambaran mendalam mengenai supervisi pembelajaran yang dilakukan oleh kepala sekolah/ madrasah.

\section{B. Pembahasan}

1. Ringkasan Artikel

Dalam meningkatkaan mutu pembelajaran kepala sekolah/ madrasah dapat dilakukan dengan cara merencanakan supervisi pembelajaran dalam bentuk rancangan yang tercantum dalam program kerja dan program supervisi kepala madrasah. Adapun tujuan diadakan supervisi dimaksudkan sebagai usaha mendorong pada guru untuk meningkatkan kompetensi dan profesionalnya agar dapat mencapai tujuan yang lebih baik dan mingkatkan prestasi siswa atau hasil belajar siswa.

Pentingnya supervisi juga tampak pada fenomena yang ada, bahwa pihak kementerian agama terus mengupayakan terwujudnya pelayanan pedidikan yang berkualitas terutama di madrasah, pelaksanaan supervisi diharapkan mampu: 1) meningkatkan kualitas dan profesionalisme guru dalam proses pembelajaran, 2) memberdayakan tim pelaksana supervisi pembelajaran di madrasah, 3) memfokuskan pada kompetensi profesional dan kompetensi pedagogik guru, 4) mengaktifkan fungsi dan tanggung jawab serta kewenangan kepala madrasah sebagai pelaku supervisi di lembaga madrasah. Dengan begitu jelas bahwa secara keseluruhan 
supervisi merupakan tugas pokok dan tanggung jawab kepala madrasah.

2. Kajian Analitis

Supervisi adalah usaha menberi layanan kepada para guru yang bertujuan untuk memperbaiki pengajaran agar menghasilkan lulusan yang berkualitas dan tercapainya hasil akhir supervisi yaitu meningkatkan prestasi siswa atau hasil belajar siswa.

Menurut Makawimbang (Abadi, Yumnan., Akhyak \& Fuadi, 2019) menyebutkan supervisi diartikan dengan pembinaan yang diberikan kepada seluruh staf sekolah agar mereka dapat meningkatkan kemampuan untuk mengembangkan situasi belajar mengajar yang lebih baik. Menurut Sofyan dkk (Abadi, Yumnan., Akhyak \& Fuadi, 2019) menjelaskan bahwa supervisi pembelajaran merupakan bagian yang tidak bisa dipisahkan dengan supervisi pendidikan. Secara substansial, supervisi pendidikan adalah suatu upaya yang dilakukan untuk meningkatkan mutu proses pendidikan yang dilaksanakan di sekolah/ madrasah, yang didukung dengan optimalisasi peran guru, ketersediaan sarana dan prasarana, desain kurikulum, sistem pembelajaran dan mekanisme penilaian dan pengukuran.

Supervisi yang dilakukan kepala sekolah diatur dalam Permen Diknas No 13 Tahun 2007 tentang Standar Kepala Sekolah/Madrasah. Menurut Ahmad sabandi (Sabandi, 2013) dimensi kopentensi supervisi kepala sekolah yang meliputi: 1) merencanakan program supervisi akademik dalam rangka peningkatan profesionalisme guru, 2) melaksanakan supervisi akademik terhadap guru dengan menggunakan pendekatan dan teknik yang sangat terbatas dan dengan kemampuan yang variatif sehingga tidak mampu melayani kebutuhan supervisi guru dalam jumlah yang besar.

Peningkatan mutu pendidikan merupakan tugas yang tidak mudah karena dipengaruhi oleh beberapa faktor seperti mutu masukan pendidikan, mutu SDM pendidikan, mutu guru dan pengelolaan pendidikan, mutu proses pembelajaran, dan kemampuan mengelola pendidikan.

Sebagai pemimpin, kepala sekolah/ madrasah berkewajiaban meningkatkan kinerja dan profesional guru dalam melaksanakan proses 
pembelajaran yang efektif. Kepala madrasah sebagai pemimpin pendidikan adalah menciptakan situasi pembelajaran sehingga para guru dapat mengajar dengan baik dan siswa pun dapat belajar dengan baik pula.

Secara institusional menurut Burhanudin (Abadi, Yumnan., Akhyak \& Fuadi, 2019) menjelaskan bahwa pengembangan dan peningkatan kompetensi, dan kinerja guru dapat dilakukan melalui upaya bantuan profesional yang memungkinkan guru tumbuh dan berkembang dan meningkatkan kemampuan profesionalnya serta belajar meningkatkan kepasitas profesionalnya yaitu berupa supervisi.

\section{Kesimpulan dan Saran}

1. Kesimpulan

Upaya untuk meningkatkan mutu pembelajaran mengacu pada tugas pokok dan kompetensi kepala madrasah yaitu melaksanan supervisi pembelajaran. Dalam meningkatkaan mutu pembelajaran kepala sekolah/ madrasah dapat dilakukan dengan cara merencanakan supervisi pembelajaran dalam bentuk rancangan yang tercantum dalam program kerja dan program supervisi kepala madrasah. Adapun tujuan diadakan supervisi dimaksudkan sebagai usaha mendorong pada guru untuk meningkatkan kompetensi dan profesionalnya agar dapat mencapai tujuan yang lebih baik dan mingkatkan prestasi siswa atau hasil belajar siswa.

supervisi merupakan bagian yang sangat penting dan tidak dapat dipisahkan dalam upaya meningkatkan mutu pendidikan baik yang ada di sekolah maupun di madrasah. Oleh karena itu, mutu pendidikan tidak bisa terlepas dengan adanya proses pendidikan dan pengajaran yang berlangsung pada suatu lembaga pendidikan yang mengupayakan pengoordinasian secara sistematis dan terencana.

2. Saran

Diharapkan kepala sekolah/ madrasah dalam kegiatan supervisi difokuskan kepada guru dalam pembelajaran agar mutu siswa menjadi lebih baik dan hasil belajar siswa meningkat.

\section{Referensi}


Abadi, Yumnan., Akhyak \& Fuadi, I. (2019). Supervisi Pembelajaran Kepala Madrasah Dalam Meningkatkan Mutu Pembelajaran. JMSP (Jurnal Manajemen Dan Supervisi Pendidikan), 3(2), 36-44. Retrieved from http://journal2.um.ac.id/index.php/jmsp/

Sabandi, A. (2013). Supervisi Pendidikan Untuk Pengembangan Profesionalitas Guru Berkelanjutan. Pedagogi, Jurnal IImiah IImu Pendidikan, XIII(2), 1-9. Retrieved from http://ejournal.unp.ac.id/index.php/pedagogi 